\title{
The Interaction Effect of Personality Factor on Capability and Competence Requirement
}

\author{
Ala'a Zuhair Mansour \\ Universiti Utara Malaysia UUM, Malaysia \\ Aidi Ahmi \\ Universiti Utara Malaysia UUM, Malaysia \\ Oluwatoyin Muse Johnson Popoola \\ Universiti Utara Malaysia UUM, Malaysia
}

Received: November 23, 2020 Accepted: December 14, 2020 Published: January 20, 2021

doi:10.5296/ber.v11i1.17982

URL: https://doi.org/10.5296/ber.v11i1.17982

\begin{abstract}
The auditing and accounting profession recently faced many challenges following fraudulent practices among the Jordanian public sector. The continuation of such fraudulent activities in the public sector impedes national economic developments and growth. This study's main objective is to have a practical and effective way of reducing the incidences of fraud in the Jordanian public sector. Specifically, this research explores the moderating role of neuroticism on knowledge requirements and fraud risk assessment performance in the Jordanian public sector. Adopting a survey method, the respondents of this study are forensic accountants and auditors in the Jordanian public sector. The research findings will contribute to the existing literature on forensic accountants, auditors, knowledge capability requirement, and neuroticism as a personality factor and fraud risk assessment performance of regulators regarding prevention and detection of fraud in the Jordanian public sector work environment.
\end{abstract}

Keywords: Fraud risk assessment, Personality factors, Knowledge, Forensic accounting, Auditing, Jordanian public sector

\section{Introduction}

In the last 25 years since the Enron crisis, the main issue in economies and countries was the prevention of fraud and corruption. It has also become an essential requirement for 
productive nations to improve the expertise of auditors and prosecutors. Fraud has become major costs for many organisations (Bierstaker, Brody, \& Pacini, 2006). It exists in almost any type of organisation and creates constant and increasing problems for companies (Zahra, Korri, \& Yu, 2005).

Following "the Statement on Auditing Standard (SAS) No. 99, Consideration of Fraud in a Financial Statement Audit", auditors of U.S. public companies are mandatory to perform a fraud risk assessment as part of financial statements audit to detect material financial misstatements (Kassem \& Higson, 2012; Victoravich, 2010). Organisations need to develop an effective fraud prevention method and detection, because it can decrease the possibilities for fraud (Bierstaker, Brody and Pacini, 2006). These procedures may include administrative communication concerning intolerance to fraudulent activities, the execution of transparent performance and remuneration schemes, pre-employment and ongoing screening, and most significantly, the promotion of a culture of fraud awareness (PricewaterhouseCoopers, 2012). According to the survey conducted by the World Economic Forum's Global Competitiveness in 2014, fraud and corruption were considered as one of the obstacles to investment in Jordan.

Fraud is still widespread in Jordan and the continuing serious financial collapses, for instance, the Petra Bank embezzlement crisis resulted in the loss of certain JD200 million (USD670 million). This crisis contributed to a decrease in the financial strength of the country which led to the depreciation of the Jordanian Dinar (1JD = USD 3.35 to USD 1.41) after this crisis; which also led to more failures of companies and increased country unemployment (Zureigat, 2015; Al-Awaqleh, 2008).

Fraud Risk Assessment (FRA), one of the components of the internal control, indicates not only the course of accounting and audit but assists auditors and forensic accountants in ascertaining organisational conditions and the extent of the audit, which are arranged to prevent, deter, and respond to fraud (COSO, 2019). Consequently, in response to the audit process, FRA is directly linked to the auditors' capability to detect and prevent fraud (Mansour et al., 2020; Popoola et al., 2015; Popoola, 2014; Chui, 2010).

For forensic accountants and auditors to be effective and efficient, they need to gain more specialised knowledge, improved abilities, and fraud-related mentality (Salleh et al., 2019; Howieson, 2018; Bhasin, 2015; DiGabriele, 2008). Improvement of the ability requirement is vital to significantly influence changing perceptions and understanding of fraud schemes and the effects of fraud in the public-sector environment. However, the latest studies have shown that it is not easy and simple for auditors to detect fraud as companies sometimes take steps to mask fraud through deliberate means (DeZoort \& Harrison, 2018; Knapp \& Knapp, 2001).

Ashton (1999) suggested that certain personality factors are individual predictive performances (i.e. fraud risk assessment), and various elements related to the essential aspects of the big-5 factors. The big-5 factors are "agreeableness, extraversion, conscientiousness, openness to experience, and neuroticism" (Goldberg, 1990). The current study assumes that highly neurotic forensic accountants and auditors would not perform well in their employment as opposed to forensic accountants and low-neuroticism auditors. The 
reason addressed is that people with high-level neuroticism continue to display negative attitudes such as fear, depression, lack of courage, and anxiety. When such attitudes are demonstrated, the current research assumes that forensic accountants and auditors might not be willing to prevent and detect fraud appropriately. Therefore, the present study suggested that a forensic accountant or high-level auditor with neuroticism will decrease the interaction among the capability to assess fraud risk task and the knowledge requirement of forensic accountants and auditors in any fraud circumstances because neurotic persons put themselves into conditions that encourage negative effect. Based on prior literature, it is evident that there are corrupt practices and fraud in the Jordanian public sector. The growth in fraud necessitates the need to carry out this research to examine the moderating effect of neuroticism on FRAP and knowledge requirements in Jordan's public sector.

The current research paper is organised as follow; Section 2 of this paper covers the literature review of fraud, internal control concept, the competency requirement (fraud risk assessment performance), capability requirement (knowledge) and neuroticism as personality factors; Section 3 presents the conceptual and theoretical framework of this study; Section 4 shows the Hypothesis Development, and; The conclusion of this research is exposed in Section 5.

\section{Literature Review}

\subsection{Fraud Concept}

In 2009, The Chartered Institute of Management Accountants (CIMA) defined 'fraud' as "all activities such as fraud by robbery, fraud by conspiracy, money laundering, bribe, and properties obtaining". Hopwood, Leiner, and Young (2012) defined 'fraud' as "the intention to cheat to get assets from the victims". While Singleton et al. (2006) demonstrate that 'fraud' is the "behaviour of human beings in the way of cruel and defalcation, immorality, illegality, or have an intention to avoid the laws, including any actions against the positions, responsibilities, and other rights", and Klitgaard (1988) and Heywood (1997) identified that 'corruption' is "a behaviour that deviates from regular responsibilities of the public services for private benefits by violating the rules and regulations with the abuse of power". In conclusion, fraud and corruption mean the swindle, deception, cheat, misappropriation, or intention to cause misunderstanding for seeking benefits both in terms of financial and nonfinancial to acquire the gains on position, power, money, property, or legal right toward oneself and companion from the organisation which that person works. This is following the theoretical concept of human needs (Need Theories) of Maslow (1943), it depends on each individual's behaviour through five aspects which are as follows: “(1) physiological needs, (2) safety needs, (3) belongingness and love needs, (4) esteem needs, and (5) self-actualisation needs". This explains all human beings struggle and fight for their own goals.

\subsection{Internal Control Concept}

Internal Control means the operating system organised within the organisations to reduce the potential risks from fraud, and it might cause damages to the properties of the organisation. Organising a good internal control system is essential for enhancing the operations to achieve organisational conduction goals, both in contexts of efficiency and effectiveness, including 


\section{Macrothink}

Business and Economic Research

ISSN 2162-4860

2021, Vol. 11, No. 1

constructing the reliability of the financial report. Furthermore, internal control includes the following laws and related rules and regulations to prevent fraud or resources misuse, which will reduce the possible mistakes from all operational activities (Clinton, Pinello, and Skaife, 2014). It consists of 5 elements as follows: “(1) Control Environment (2) Risk Assessment (3) Control Activities (4) Information and Communication and (5) Monitoring" as shown in Figure 1. In 2013, the Committee of Sponsoring Organisations of the Treadway Commission (COSO) developed the guidelines of internal control and investigation by increasing the intensity of the analysis and risks from five factors previously to eight factors focusing on the behavioural analysis of the wrongdoer on fraud based on Fraud Triangle concept by Cressey. Cressey $(1953,1951)$ revealed that "the fraud behaviours are caused by three motivation, which includes incentive/pressure, opportunity, and attitudes/rationalisation. Singleton et al. (2006) said that if an organisation has a weakness in the internal control systems, it will open up the opportunity to fraud.

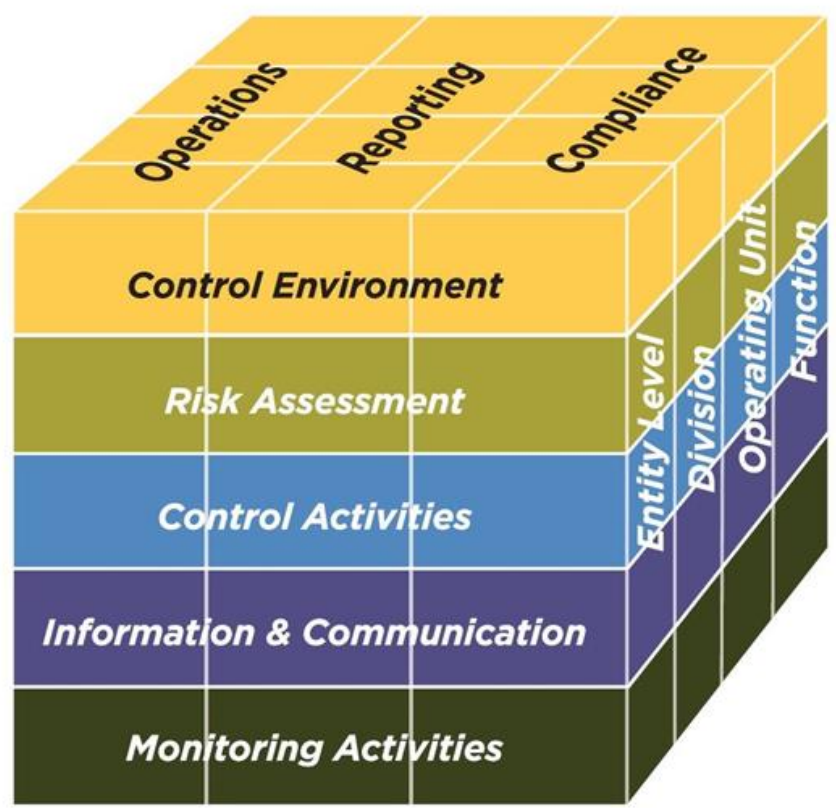

Figure 1. The Five Elements based on the COSO Model

\subsection{Capability and Competence Requirements}

The International education standard No 8, Competence requirements for audit professionals produced by the IAESB, an organ of the IFAC suggests requirements for accountants who assume the audit professional's role and also who have the responsibility to make essential judgments in audit of historical financial information in specific working environments and industries (IFAC-IES, 2006). Capability defined as "the professional knowledge, professional skills, professional values, ethics, and attitudes required to demonstrate competence" (IFACIES 8.8, 2006). This standard also explains "capability" to mean the attribute of persons who can play their tasks at work environment efficiently. The term capability comprises "content knowledge, technical and functional skills, behavioural skills, intellectual abilities 
(including professional judgements) and professional values, ethics and attitudes" (WAC-ES $8,2006)$. Competence is defined as the actual demonstration of performance. Also, it relates to the capability to do work tasks in the actual working environment according to a defined standard (IFAC-IES 8.8, 2006).

\subsection{Fraud Risk Assessment Performance FRAP}

According to COSO framework components and principles, their indicators are considered essential for risk assessment (COSO, 2019 p.6). The component and principle of risk assessment are: "1) specifies suitable objectives, 2) Identifies and analyses risk, 3) Assesses fraud risk, and 4) Identifies and analyses significant change". FRAP is "a complex process carried out by auditors that require advanced cognitive knowledge and skills" (Desai \& Gupta, 2016). Fraud risk assessment (FRA) helps an auditor to understand the complexity of the audit processes needed to increase the likelihood of detecting fraud (Wuerges, 2011; Bloomfield, 1997). Regrettably, prior studies have presented that auditors are typically not adequately capable of assessing fraud risk, therefore, cannot detect fraud in a financial statements audit (Asare et al., 2015; Wuerges, 2011; Allen et al., 2006). Following "the Statement on Auditing Standard (SAS) No. 99, Consideration of Fraud in a Financial Statement Audit", auditors of U.S. Government companies are required to execute FRA as part of audits of the financial statements to avoid material financial errors (Kassem \& Higson, 2012; Victoravich, 2010).

According to the American Institute of Certified Public Accountants (AICPA) in "Managing the Business Risk of Fraud: A Practical Guide" (2009) "An efficient FRA ought to determine where fraud might happen and who the perpetrators might be. Therefore, control activities should always consider both the fraud scheme and the individuals within and outside the organisation who could be the perpetrators of each scheme. If the scheme is collusive, preventive controls should be augmented by detective controls, as collusion negates the control effectiveness of segregation of duties".

In addition, FRA is considered as a useful method for prevention of fraud, accordingly, was endorsed to improve auditor's competence in the quest for fraud prevention and detection (Mansour et al., 2020; Baz et al., 2016; Payments, 2015; Subramanian, 2014; Knapp \& Knapp, 2001). For this study, FRA performance is defined as the forensic accountant and auditor's capability to access fraud risk to prevent and detect fraud within the public sector's working environments.

\subsection{Knowledge Requirement}

Knowledge of forensic accounting includes "professional responsibilities and practice management, laws, courts and dispute resolution, planning and preparation, information gathering and preservation (documents, interviews or interrogations, electronic data), finding, reporting, experts and testimony" (Lessambo, 2018; Popoola et al., 2015; Popoola et al.,2014; Davis et al., 2010; Durkin \& Ueltzen, 2009). Seven fields are defined as a component of specialised knowledge in forensic accounting, according to "the American Institute of Certified Public Accountants" (Davis et al., 2010). These areas comprise "fraud prevention, 
detection and response, computer forensic analysis, family law, valuation, financial statement misrepresentation, economic damages calculations, and bankruptcy, and insolvency and reorganisation" (AICPA, 2011; Durkin and Ueltzen, 2009). The current research paper includes fraud detection, prevention, and response to highlight the potential failure to manage Jordan's accounting and auditing systems. A forensic accountant must have the necessary resources to detect fraud built on his education and training on communications, legal and criminology, information technology, and investigation (Popoola, Che-Ahmad \& Samsudin, 2015; Davis et al., 2010).

Recent studies have shown that individuals with specialised knowledge in the use of information technology, legal investigative criminology and accounting would be useful at documenting and processing reports, reviewing financial statements, questioning and acting as professional witnesses than individuals in auditing (Hopwood et al., 2012; Singleton et al., 2006). The International Education Standard No 8, Competence Requirements for Professional Accountants, identifies the auditors' knowledge capability to include "historical financial information audit at a higher level, financial accounting and reporting at a higher standard, and information technology" (IFAC, 2019).

This research agrees with the Association of Certified Fraud Examiners (ACFE) that standard-setter statements are not appropriate for identifying fraud (ACFE, 2018). Popoola (2014) noted that the identification and reaction of fraud prevention is not just a piece of cake and requires much more than the explanations in IES No. 8, Audit Professional Competence Requirements (IFAC, 2019).

\subsection{Neuroticism as a Personality Factor}

Over the current century, previous literature, and analyses from across several nations and cultures have addressed the impact of Big-5 personality as the most powerful impact on task performance to explain how personality traits can impact task performance. Over the years, studies have defined several personality factors that may reflect person traits (McCrae \& Terracciano, 2005; McCrae \& Costa, 1997). For instance, the Big-5 personality ("extraversion, neuroticism, conscientiousness agreeableness and openness to experience") represents individual interactions and behavioural response in a different environment, for example, task performance (Trouba, 2009; Vakola et al., 2004).

Numerous studies have highlighted the important influence between Big-5 personality and auditor's behaviour (Mansour et al., 2020; Asni et al., 2018; Asmara, 2016; Donelly et al., 2003; Dole \& Schroeder, 2001; Tsui \& Gul, 1996); Auditors' judgement (Tsunogaya et al., 2017; Lehmann, 2001); workload and job exhaustion (Law, 2003); Opinion of managers (Hartmann, 2005). Hence, this previous empirical research found inconsistent results about the effect of the Big-5 factors on individual performance (fraud risk assessment).

As per McCrea and John (1992), neuroticism signified individual differences in the inclination to experience distress and the cognitive and behavioural styles that follow from this tendency. They stated that neuroticism highlights anxious, self-pitying, tense, sensitive, unbalanced, and worrying behaviours. Goldberg (1993) posits that neuroticism comprises 
individual characteristics such as anxiety, emotional instability, and tempera.

The Big-5 factors of personality have been investigated in many studies, including vigilance performance and workload. Rose et al. (2002) found that neuroticism was linked to perceived frustration in terms of perceived workload. Prior researches provided inconsistent results on the impact of neuroticism as a personality factor on individual performance (e.g. Mansour et al., 2020; Gullkvist \& Jokipii, 2015; Jaffar et al., 2011; Zimbelman \& Waller, 1999; Bernardi, 1994; Pincus, 1984). Current research assumes that forensic accountants and auditors with high neuroticism will not perform efficiently and effectively in their work matched to those with low neuroticism as those with high-level neuroticism appear to have negative attitudes. This research assumes that the auditors might not be capable to effectively detecting the risk of fraud if such attitudes are demonstrated.

\section{Conceptual Framework of the Study}

A conceptual framework relates to a structure of rules, assertions and principles that incorporates ideas about a particular concept (Mugenda \& Mugenda, 2003). The conceptual framework is intended to explore the moderating effect of neuroticism, the forensic accountants, and auditor's knowledge capability on FRAP in the Jordanian public sector. Figure 2 presented the research framework of this paper.

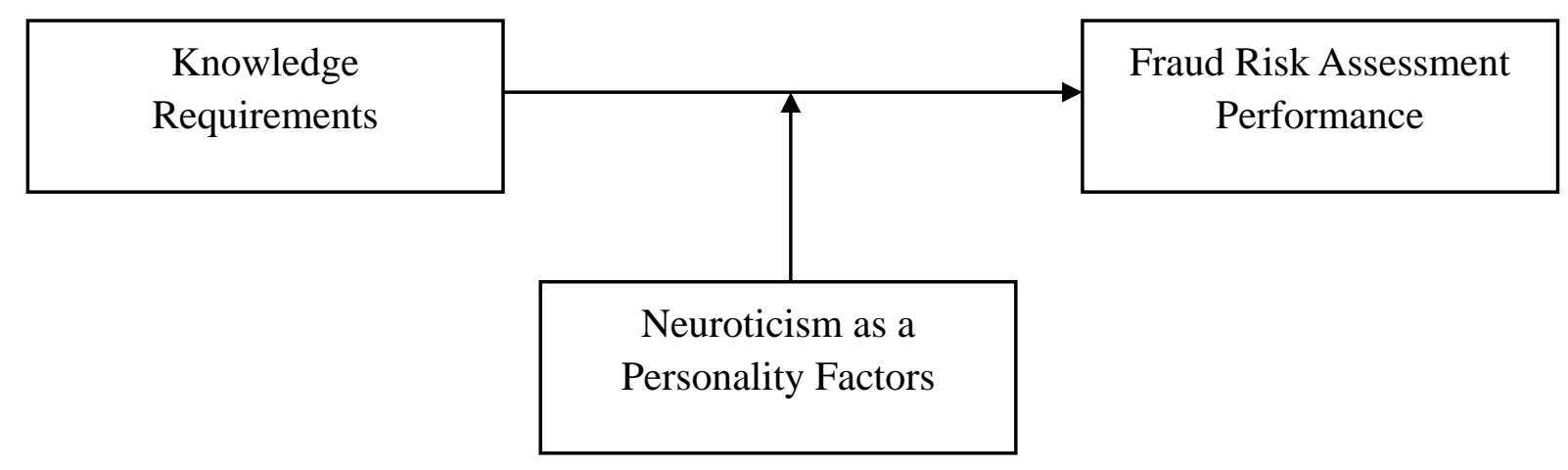

Figure 2. Conceptual Framework of the Study

\section{Hypothesis Development}

\subsection{Knowledge Requirement and Fraud Risk Assessment Performance}

First conceptual connection in the current research is the knowledge requirement effect on the FRAP. As stated by International Education Standard No. 8, competency requirements for audit professionals, auditor's knowledge is divided into three: (1) higher-level of historical financial information analysis, (2) higher-level financial accounting and monitoring, and (3) IT. (IFAC-IES, 2019). This research paper agrees with Daniel and Lee (2006) that the charts may be looked at by other accountants, but forensic accountants look deep into the body. Prior studies, suggested that a modest change in knowledge capability produces considerable changes in performance and possess an imposing impact on person's resolve, assertiveness, and commitment to achieve set objectives (Mansour et al., 2020; Popoola et al., 2015; 


\section{$\triangle$ Macrothink}

Business and Economic Research ISSN 2162-4860

2021, Vol. 11, No. 1

Hopwood, Leiner, and Young, 2012; Davis, Farrell \& Ogilby, 2010; Di-Gabriele, 2008; Messmer, 2004; Haris \& Brown, 2000). The current study proposes the following hypothesis:

H1: There is a relationship between knowledge requirement and fraud risk assessment performance in the Jordanian public sector.

\subsection{Neuroticism and Fraud Risk Assessment Performance}

The second conceptual relation in the current study is the influence of neuroticism as a personality factor on FRAP. Neuroticism is a dimension of big-five factors that tend to experience adverse impacts like fear, sorrow, confusion, irritation, fault, and loathing. Some kinds of psychiatric problems may be at risk for high level. A high level of neuroticism indicates that individuals are vulnerable to illogical beliefs are less capable of controlling urges and poorly to deal with stress. A low level of neuroticism shows emotional stability. Usually, such people are generally calm, quiet, confident, and capable of handling stressful situations without getting upset (Warrington, 2017; Rothmann \& Coetzer, 2003; Hough et al., 1990).

The previous study found neuroticism as a forecaster of performance in different professions (Tuteja \& Sharma, 2016; Hörmann \& Maschke 1996). Dunn, Mount, Barrick, and Ones (1995) indicated that the second most important feature affecting candidates ' employability is emotional stability (the opposite of neuroticism). A recent study stated that neuroticism is backwards linked to task performance (Terrier, Kim, and Fernandez, 2016; Judge Higgins, Thoresen, and Barrick, 1999). However, Salgado (1997), in certain circumstances, argued that neuroticism predicts job performance. This study proposes that forensic accountants and auditors' high neurotic behaviour would not be capable of performing effectively in their work matched to those with lower neuroticism as those with a high level of neuroticism tend to have negative attitudes. The present study proposes the following hypothesis:

$\mathrm{H} 2$ : There is a relationship between neuroticism and fraud risk assessment performance in the Jordanian public sector.

\subsection{The Moderating Effect of Neuroticism on Knowledge Requirements and Fraud Risk Assessment Performance}

The third conceptual link in this research is the interaction effect of neuroticism between knowledge (forensic accountants and auditors) and FRAP. The impact of neuroticism on performance is found to have mixed results (e.g. Mansour et al., 2020; Gullkvist \& Jokipii, 2015; Jaffar et al., 2011; Zimbelman \& Waller, 1999; Bernardi, 1994; Pincus, 1984). The current study posits that forensic accountants and auditors with a highly neuroticism would not perform effectively in their work than those with a lower neuroticism level, as those with high neuroticism appear to have negative attitudes. Thus, the current research suggests that a high level of neuroticism would reduce the relationship between knowledge (capability requirements) and assess fraud risk in any fraud situation. This research, therefore, postulates thus:

H3: Neuroticism positively moderates the relationship between knowledge requirement and 
fraud risk assessment performance in the Jordanian public sector.

\section{Research Methodology}

This study plans to employ a quantitative approach through a survey to test the hypothesis. A questionnaire is developed to be distributed to forensic accountants and auditors from the Audit Bureau and Integrity and Anti-Corruption Commission in Jordan. The study will use the Statistical Package for Social Sciences (SPSS) version24 as a data analysis technique (Zikmund \& Griffin, 2013) and Structural Equation Modelling Partial Least Squares (SEM-PLS) for data analysis to determine the overall predictive quality or relevance of the model, confirmatory factor analysis (CFA), amongst others (Hair et al., 2014).

\section{Conclusion}

This research investigated the moderating influence of neuroticism as a personality factor on the association among knowledge of (forensic accountants and auditors) FRAP in the public sector in Jordan, having expanded on the issue statement and research objectives. The research helps to understand forensic accounting processes of fraud detection, improved fraud mediation, and reactions on the environment of the public sector. In addition, the relevant literature on the capability requirements of forensic accountants and auditors and the moderating influence of neuroticism as a personality factor in the Jordanian public sector's FRA and capability requirements are reviewed. This research paper offers a conceptual framework that could be used to deter and detect fraud by forensic accountants and public sector auditors. The current research is theoretical in nature, and thus, more empirical research on this topic needs to be undertaken to determine the importance of FRAP.

\section{References}

ACFE. (2018). Report to the Nation: Global study on occupational fraud and abuse. TX: Association of Certified Fraud Examiners.

Al-Awaqleh, Q. A. Q. (2008). Going-concern Evaluation in Jordan. (Doctoral Dissertation) Universiti Utara Malaysia.

Ala'a Zuhair Mansour, A. A., \& Popoola, O. M. J. (2020). The Personality Factor of Conscientiousness on Skills Requirement and Fraud Risk Assessment Performance. International Journal of Financial Research, 11(2), 405.

https://doi.org/10.5430/ijfr.v11n2p405

Allen, R. D., Hermanson, D. R., Kozloski, T. M., \& Ramsay, R. J. (2006). Auditor Risk Assessment: Insights from the Academic Literature. Accounting Horizons, 20(2), 157-177. https://doi.org/10.2308/acch.2006.20.2.157

Amiri, A. Y. (2018). An investigation of the effects of litigation and interrogation skills of forensic accounting on fraud risk valuations: an empirical study of government auditors in Dubai, United Arab Emirates. (Doctoral Dissertation) The University of Wollongong in Dubai.

Asare, S. K., Wright, A., \& Zimbelman, M. F. (2015). Local buckling capacity of steel 
I-section beams subjected to a uniform or linear temperature gradient. Journal of Forensic \& Investigative Accounting, 7(2), 63-112. https://doi.org/10.1016/j.tws.2017.06.017

Asmara, R. Y. (2016). Effect of competence and motivation of auditors of the quality of audit: Survey on the external auditor registered public accounting firm in Jakarta in Indonesia. European Journal of Accounting, Auditing and Finance Research, 4(1), 43-76.

Asni, N., Dali, N., Tuti, D., \& Syafitri, A. A. (2018). The Influence of Locus of Control and Professional Commitment toward Auditor's Behaviour in Conflict Situation. IOSR Journal of Economics and Finance (IOSR-JEF), 9(4), 75-83. https://doi.org/10.9790/5933-0904037583

Baz, R., Samsudin, R. S., Che-Ahmad, A. B., \& Popoola, O. M. J. (2016). Capability component of fraud and fraud prevention in the Saudi Arabian banking sector. International Journal of Economics and Financial Issues, 6(4), 68-71.

Bernardi, R. A. (1994). Fraud detection: The effect of client integrity and competence and auditor cognitive style. Auditing, 13, 68.

Bhasin, M. (2015). Survey of Skills Required by the Forensic Accountants: Evidence from a Developing Country. International Journal of Contemporary Business Studies, 4(2), 54-86. https://doi.org/10.2139/ssrn.2676514

Bierstaker, J. L., Brody, R. G., \& Pacini, C. (2006). Accountants' perceptions regarding fraud detection and prevention methods. Managerial Auditing Journal, 21(5), 520-535.

https://doi.org/10.1108/02686900610667283

Bloomfield, R. J. (1997). Strategic dependence and the assessment of fraud risk: A laboratory study. Accounting Review, 72(4), 517-538.

COSO. (2019). Internal Control-Integrated Framework. Committee of Sponsoring Organisations of the Tredway Commission. New York, NY.

COSO. (2016). Fraud Risk Management Guide. Committee of Sponsoring Organisations of the Tredway Commission. New York, NY.

COSO. (2013). Internal Control Framework Committee of Sponsoring Organisations of the Tredway Commission. Committee of Sponsoring Organisations of the Tredway Commission. New York, NY.

Chui, L. (2010). An Experimental Examination of the Effects of Fraud Specialist and Audit Mindsets on Fraud Risk Assessments and the Development of Fraud Related Problem Representations. (Doctoral Dissertation) The University of North Texas.

Clinton, S. B., Pinello, A. S., \& Skaife, H. A. (2014). The implications of ineffective internal control and SOX 404 reporting for financial analysts. Journal of Accounting and Public Policy, 33(4), 303-327. https://doi.org/10.1016/j.jaccpubpol.2014.04.005

Cressey, D. R. (1953). Other people's money; a study of the social psychology of embezzlement. 


\section{Macrothink}

Business and Economic Research ISSN 2162-4860 2021, Vol. 11, No. 1

Davis, C., Farrell, N., \& Ogilby, S. (2010). Characteristics and skills of the forensic accountant. AICPA FVS Section. American Institute of Certified Public Accountants, 11-23.

DeZoort, F. T., \& Harrison, P. D. (2018). Understanding Auditors' Sense of Responsibility for Detecting Fraud within Organisations. Journal of Business Ethics, 149(4), 857-874. https://doi.org/10.1007/s10551-016-3064-3

DiGabriele, J. A. (2008). An Empirical Investigation of the Relevant Skills of Forensic Accountants. Journal of Education for Business, 83(6), 331-338.

https://doi.org/10.3200/JOEB.83.6.331-338

Dole, C., \& Schroeder, R. G. (2001). The impact of various factors on the personality, job satisfaction and turnover intentions of professional accountants. Managerial Auditing Journal, 16(4), 234-245. https://doi.org/10.1108/02686900110389188

Dunn, W. S., Mount, M. K., Barrick, M. R., \& Ones, D. S. (1995). The relative importance of personality and general mental ability in managers' judgments of applicant qualifications. Journal of Applied Psychology, 80(4), 500-509. https://doi.org/10.1037/0021-9010.80.4.500

Durkin, R., \& Ueltzen, M. (2009). The evolution of the CFF credential. The Practicing CPA, $33(6)$.

Goldberg, L. R. (1990). An alternative "description of personality": The Big-Five factor structure. Journal of Personality and Social Psychology, 59(6), 1216-1229.

https://doi.org/10.1037/0022-3514.59.6.1216

Gullkvist, B., \& Jokipiii, A. (2015). Factors influencing auditors' self-perceived ability to assess fraud risk. $N J B, 64(1), 40-63$.

Hair, Jr, J., Sarstedt, M., Hopkins, L., \& G. Kuppelwieser, V. (2014). Partial least squares structural equation modelling (PLS-SEM). European Business Review, 26(2), 106-121. https://doi.org/10.1108/EBR-10-2013-0128

Harris, C. K., \& Brown, A. M. (2000). The qualities of a forensic accountant. Pennsylvania CPA Journal, 71(1), 6.

Heywood, P. (1997). Political corruption: Problems and perspectives. Political Studies, 45(3), 417-434. https://doi.org/10.1111/1467-9248.00089

Hopwood, W. S., Leiner, J. J., \& Young, G. R. (2012). Forensic accounting and fraud examination. McGraw-Hill New York, NY.

Hormann, H.-J., \& Maschke, P. (1996). On the Relation between Personality and Job Performance of Airline Pilots. International Journal of Aviation Psychology, 6(2), 171-178.

Hough, L. M., Eaton, N. K., Dunnette, M. D., Kamp, J. D., \& McCloy, R. A. (1990). Criterion-Related Validities of Personality Constructs and the Effect of Response Distortion on Those Validities. Journal of Applied Psychology, 75(5), 581-595.

https://doi.org/10.1037/0021-9010.75.5.581 
Howieson, B. (2018). What is a 'good' forensic accountant? A virtue ethics perspective. Pacific Accounting Review, 30(2), 155-167. https://doi.org/10.1108/PAR-01-2017-0005

IFAC. (2019). International Education Standard No. 8, Competence Requirements for Audit professionals. New York: International Federation of Accountants.

IFAC. (2006). International Education Standard No. 8, Competence Requirements for Audit professionals. New York: International Federation of Accountants.

Jaffar, N., Salleh, A., Iskandar, T. M., \& Haron, H. (2008). The effect of the external auditors' ability to assess fraud risk on their ability to detect the likelihood of fraud. International Journal of Management Perspectives, 1(1), 49-70.

Judge, T. A., Higgins, C. A., Thoresen, C. J., \& Barrick, M. R. (1999). The Big Five Personality Traits, General Mental Ability, and Career Success across the Life Span. Personnel Psychology, 52(3), 621-652. https://doi.org/10.1111/j.1744-6570.1999.tb00174.x

Kassem, R., \& Higson, A. (2012). Financial Reporting Fraud: Are Standards' Setters and External Auditors doing enough? International Journal of Business and Social Science, 3(19), 283-290.

Kassem, R., \& Higson, A. (2012). The New Fraud Triangle Model. Journal of Emerging Trends in Economics and Management Sciences (JETEMS), 3(3), 191-195.

Klitgaard, R. (1988). Controlling corruption. University of California Press. https://doi.org/10.1525/9780520911185

Knapp, C. A., \& Knapp, M. C. (2001). The effects of experience and explicit fraud risk assessment in detecting fraud with analytical procedures. Accounting, Organisations and Society, 26(1), 25-37. https://doi.org/10.1016/S0361-3682(00)00005-2

Law, D. W. (2003). An examination of personality traits as moderating factors of exhaustion in public accounting. (Doctoral Dissertation) Washington State University.

Lehmann, C. M. (2002). The effects of experience, instruction and personality factors on complex problem representation and performance in auditing: An experimental investigation. (Doctoral Dissertation) Texas A\&M University, USA.

Lessambo, F. I. (2018). Auditing, Assurance Services, and Forensics. In Auditing, Assurance Services, and Forensics. https://doi.org/10.1007/978-3-319-90521-1

Maslow, A. H. (1943). A Theory of Human Motivation. Psychological Review, 50, 370-396.

Messmer, M. (2004). Exploring options in forensic accounting. National Public Accountant, 5(3), 19-20.

Mugenda, O., \& Mugenda, A. (2003). Research methods: Quantitative and Qualitative Methods. Revised in Nairobi.

Pincus, V. K. (1984). Fraud detection ability: Individual differences and their relationship to cognitive style difference. Unpublished Doctoral Dissertation. The University of Maryland, 
USA.

Popoola, O. M. J., Che Ahmad, A. B., \& Samsudin, R. S. (2015). An Empirical Investigation of Fraud Risk Assessment and Knowledge Requirement on Fraud Related Problem Representation in Nigeria. Accounting Research Journal, 28(1), 78-97.

https://doi.org/10.1108/ARJ-08-2014-0067

Popoola, O. M. J. (2014). Forensic accountants, auditors and fraud: capability and competence requirements in the Nigerian public sector. Doctoral Dissertation. Universiti Utara Malaysia.

PWC. (2012). Fighting fraud in the public sector. Retrieved from

https://www.pwc.com/gx/en/psrc/pdf/fighting_fraud_in_the_public_sector_june2011.pdf

Rose, C. L., Murphy, L. B., Byard, L., \& Nikzad, K. (2002). The Role of the Big Five Personality Factors in Vigilance Performance and Workload. European Journal of Personality, 16(3), 185-200. https://doi.org/10.1002/per.451

Salgado, J. F. (1997). The five-factor model of personality and job performance in the European Community. Journal of Applied Psychology, 82(1), 30-43.

https://doi.org/10.1037/0021-9010.82.1.30

Salleh, K., \& Aziz, R. A. (2014). Traits, Skills and Ethical Values of Public Sector Forensic Accountants: An Empirical Investigation. Procedia - Social and Behavioural Sciences, 145, 361-370. https://doi.org/10.1016/j.sbspro.2014.06.045

Shbeilat, M. K. (2013). The Jordanian Corporate Governance Code: A study of institutional investor's perception of the reliability of the audit report and the audit expectation gap (Australian Catholic University Research). https://doi.org/10.4226/66/5a96308fc68a1

Singleton, T. W., Singleton, A. J., Bologna, G. J., \& Lindquist, R. J. (2007). Fraud auditing and forensic accounting. Hoboken, New Jersey: John Wiley \& Sons, Inc.

Terrier, L., Kim, S., \& Fernandez, S. (2016). Who are the good organisational citizens for the environment? An examination of the predictive validity of personality traits. Journal of Environmental Psychology, 48, 185-190. https://doi.org/10.1016/j.jenvp.2016.10.005

The Chartered Institute of Management Accountants (CIMA). (2008). Fraud risk management: A guide to good practice. Chartered Institute of Management Accountants. Retrieved from

https://www.cimaglobal.com/Documents/ImportedDocuments/cid_techguide_fraud_risk_man agement_feb09.pdf.pdf

Trouba, E. J. (2009). A person-organisation fit study of the big five personality model and attraction to organisations with varying compensation system characteristics. ProQuest Information \& Learning.

Tsunogaya, N., Sugahara, S., \& Chand, P. (2017). The Impact of Social Influence Pressures, Commitment, and Personality on Judgments by Auditors: Evidence from Japan. Journal of 
International Accounting Research, 16(3), 17-34. https://doi.org/10.2308/jiar-51761

Vakola, M., Tsaousis, I., \& Nikolaou, I. (2004). The role of emotional intelligence and personality variables on attitudes toward organisational change. Journal of Managerial Psychology, 19(2), 88-110. https://doi.org/10.1108/02683940410526082

Victoravich, L. M. (2010). The mediated effect of SAS No. 99 and Sarbanes-Oxley officer certification on jurors' evaluation of auditor liability. Journal of Accounting and Public Policy, 29(6), 559-577. https://doi.org/10.1016/j.jaccpubpol.2010.09.006

Warrington, C. (2017). a Study of Personality Traits to Explain Employees' Information Security Behavior Among Generational Cohorts. Capella University.

Wuerges, A. (2011). Auditors' responsibility for fraud detection: New wine in old bottles. Retrieved on November, 3, 2012.

Zahra, S. A., Korri, J. S., \& Yu, J. F. (2005). Cognition and international entrepreneurship: Implications for research on international opportunity recognition and exploitation. International Business Review, 14(2), 129-146. https://doi.org/10.1016/j.ibusrev.2004.04.005

Zikmund, W. G., Carr, J. C., \& Griffin, M. (2013). Business research methods. Cengage Learning.

Zimbelman, M. F., \& Waller, W. S. (1999). An Experimental Investigation of Auditor-Auditee Interaction under Ambiguity. Journal of Accounting Research, 37(1999), 135.

https://doi.org/10.2307/2491349

Zureigat, B. N. (2015). Corporate Governance and the Going Concern Evaluation of Jordanian Listed Companies at Amman Stock Exchange. Universiti Utara Malaysia.

\section{Copyright Disclaimer}

Copyright for this article is retained by the author(s), with first publication rights granted to the journal.

This is an open-access article distributed under the terms and conditions of the Creative Commons Attribution license (http://creativecommons.org/licenses/by/4.0/). 